\title{
Insight into the Polish Strategy for Responsible Development by 2020 and New Structural Economics Assumptions
}

\author{
Pawel BRUSILO \\ Department of International Trade Relations \\ Wroclaw University of Economics and Business, Wroclaw, Poland \\ Email address: pawel.brusilo@ue.wroc.pl
}

Received date: 24 January 2020; Accepted date: 7 July 2020; Published date: 9 September 2020

Academic Editor: Ewa Sobolewska-Poniedziałek

Copyright (C) 2020. Pawel BRUSILO. Distributed under Creative Commons Attribution 4.0 International CC-BY 4.0

\begin{abstract}
This paper is an overview and a comparison of the new structural economics postulates and the assumptions of Polish Strategy for the Responsible Development by 2020 (with 2030 perspective). New structural economics is a modern way of thinking about economic development, which combines the postulates of neoclassical and structural economics. This doctrine accentuates the importance of the role of public institutions in reshaping industries and turning hidden comparative advantages into competitive advantages. The author undertook this study to identify several NSE assumptions in the most up to date Polish strategy of development. The discussed controversial strategy SRD 2020/2030 was supposed to make a significant contribution to Polish economic and social development as well as set priorities for public institutions for the coming years. By using analysis and criticism of available publications, literature, and relevant statistical data, the author reviews Strategy for the Responsible Development, evaluates its objectives and presents achievements in the implementation of 'flag projects' over the period 2017-2019 with appropriate criticism.
\end{abstract}

Keywords: development, Poland, strategy, new structural economics

\section{Introduction}

"(..) New structural economics may be described as a new economic doctrine which points out the traps faced by developing countries as they gradually approach the status of developed countries. Even more importantly, NSE indicates solutions and methods, enabling middle-income countries to overcome the difficulties inherent in this specific stage of growth and to catch-up with the wealthiest countries. Polish response to that doctrine is found in the form of the Strategy for Responsible Development. "

Mateusz Morawiecki, Prime Minister of Poland, 2017

The Polish economy is currently in the process of a rapid transition caused by

Cite this Article as: Pawel BRUSILO (2020)," Insight into the Polish Strategy for Responsible Development by 2020 and New Structural Economics Assumptions ", Journal of Eastern Europe Research in Business and Economics Vol. 2020 (2020), Article ID 812353, DOI: 10.5171/2020.812353 
various social and economic changes. From a political perspective, one of the most important objectives is to set priorities for the next years and accelerate the country's catching-up process towards much more developed economies (Poskrobko, 2012). The quotation above (from Polish Prime Minister's preface to one of NSE publications) clearly shows which doctrine was an inspiration to establish a new roadmap for the future development in this country (Lin and Nowak 2017). This paper aims to provide vital information about Strategy for Responsible Development by 2020 (with 2030 perspective), from now on referred to as SRD 2020/2030, and the role of new structural economics in shaping Polish economic development in the coming years.

The paper is organized as follows. The first part develops the theoretical background for a better understanding of new structural economics assumptions. The next section discusses the methodological issues and data collection procedure used in the research. The third section provides an analysis of SRD 2020/2030 postulates with its background and current, the most significant achievements. The final part of the paper discusses the results and presents policy recommendations.

\section{Literature Review}

New structural economics is a modern economic development doctrine, which combines the assumptions of well-known structural economics and neoclassical economics (Lin, 2012). It was founded and recounted, among others, by Professor Justin Yifu Lin - Dean of Institute for New Structural Economics at Peking University and former Chief Economist of the World Bank.

This economic strategy was designed to stimulate and accelerate the caching-up process of middle-income countries. The NSE postulates are based on these crucial assumptions. First of all, economic development is perceived as a process of constant structural change in the economy (Lin, 2011). Income and labor productivity is increased by technological innovations, while transaction costs are decreased by improvements in infrastructure (Bruno et al., 2015). The industrial and economic structure is endogenous regarding its endowment structure (Woźniak et al., 2018).

Secondly, the government has an essential role in shaping economic development, mostly by seeking comparative advantages and - by using industrial policy - trying to turn them into competitive advantages (Lin and Nowak, 2017). Finally, a government of a middle-income country ought to categorize the nation's sectors and industries: by their importance to the country's economy, distance to foreign developed economies, competitiveness, and hidden comparative and competitive advantages. After the review, NSE also recommends various industrial or fiscal policies towards those industries and forms of governmental support, such as special economic zones, incubation programs, industrial parks, corporate income tax holidays, or R\&D grants (Lin, 2010). In the literature, we can find a description of specific types of economic development policies matching different kinds of industries (Lin and Nowak, 2017).

This crucial assumption is related to the neoclassical economics theory of comparative costs and advantages, which was widely presented and discussed by Krugman and Obstfeld (2018).

Recommended by NSE dominant role of authorities in shaping economic development requires responsible and involved politicians with the ability to recognize comparative advantages and turn them into competitive advantages. This approach means that the success of middleincome countries is strictly related to the introduced strategy and endowment of the national economy. The summary and review of industrial policies with matched industries are placed below. 


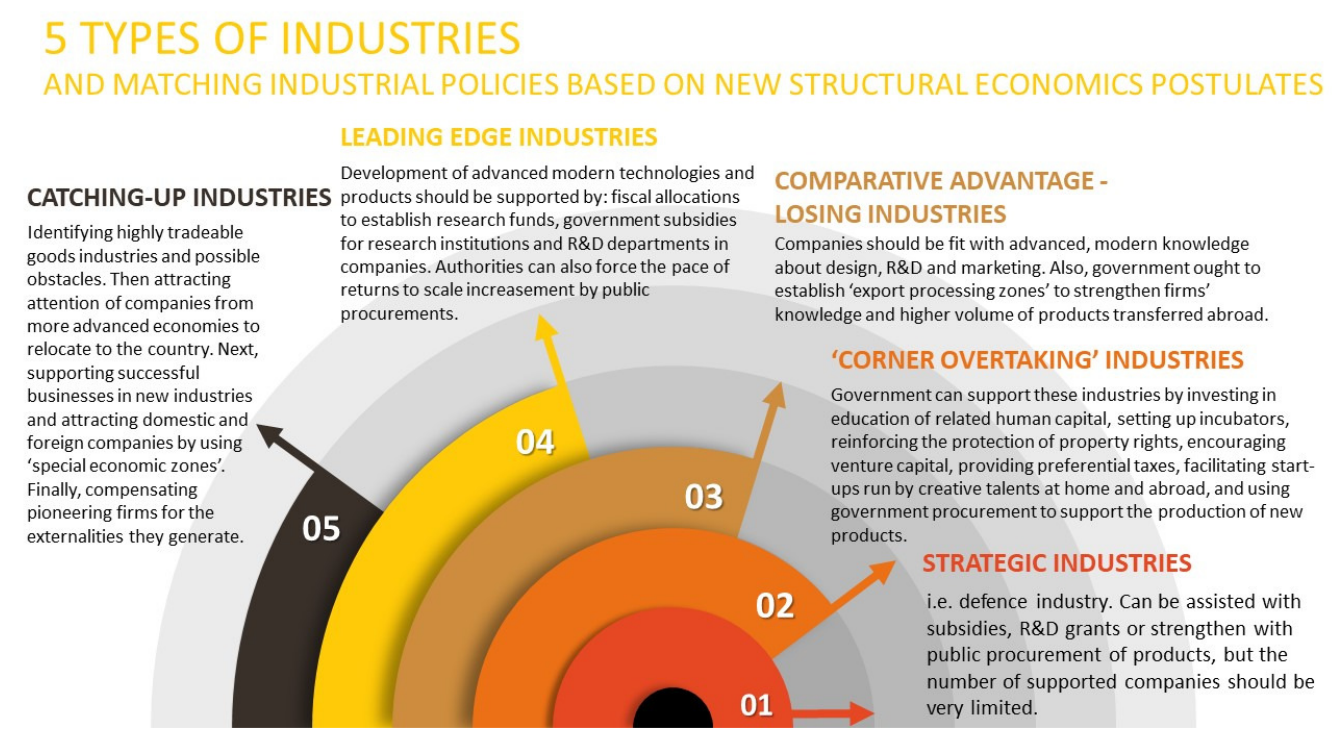

Picture 1. 5 : types of industries and matching industrial policies based on NSE assumptions. Source: Own elaboration based on Lin J. Y., Nowak A. Z. (2017) New structural economics for less advanced countries. p. 16.Warsaw: University of Warsaw Faculty of Management Press.

\section{Methods and data collection}

This study seeks to contribute, by addressing the following research questions: What are the specific aims and expectations on a field of 'Reindustrialization' in SRD 2020/2030? How were the strategic industries chosen, and what was the impact of NSE assumptions on this process? What are the 'flag projects' in SRD 2020/2030? What is a current progression in the implementation of $S R D$ 2020/2030 on a field of 'Reindustrialisation'? This study on Strategy for Responsible Development was conducted by using textual criticism as well as analysis and comparison of available regulations, literature, reports, and data about the projects included in SRD 2020/2030. Data used in the evaluation derives from sources like Central Statistical Office (GUS/ Statistics Poland), Eurostat, official publications of Council of Ministers (especially from former Ministry of Development and modern counterparts), National Centre for Research and Development, European Commission
"Innovation Union Scoreboard' (20042019) report and trade magazines.

\section{Results and Discussion}

New structural economics was established less than ten years ago and has already gained popularity among economists and politicians across the world. Since this economic doctrine is devoted to middleincome countries (with a catching-up economy), the Polish government, among others, decided to implement NSE postulates and follow its recommendations towards its industrial policy.

The Polish parliament, on February 14, 2017, passed a bill and officially introduced widely discussed and criticized Strategy for Responsible Development by 2020 (with 2030 perspective). SRD 2020/2030 constitutes the desire to accelerate economic development, increase the standard of living in Poland, implement rules of sustainable economic growth, and strengthen the Polish position within the European Union and global economy. 
The government officials acknowledged the fact that SRD 2020/2030 is also a response to challenges that Poland faces nowadays such as economic inequality, climate crisis, and demographic change, many times. SRD $2020 / 2030$ is an attempt to implement NSE assumptions in a comprehensive development strategy together with an analysis of the current situation of the Polish economy and society.

Such a development strategy was necessary, mostly because Poland became a signatory to many international treaties and agreements, such as:

- Transforming our world: the 2030 Agenda for Sustainable Development, 2015, United Nations,

- Europe 2020: the European Union strategy for growth and employment,

- European Union climate and energy package,

- European Council 2030 climate \& energy framework,

- Paris agreement, 2015, United Nations.

Implementation of these postulates, included in those treaties, required a broad strategy of social and economic development based on eco-friendly solutions.

Regarding previous Polish development strategies, SRD 2020/2030 accentuates the most the role of central authorities in industrial development policy.
Undoubtedly, Polish accession to the European Union in 2004 was one of the most critical and strategic moments in the modern history of this country.

Since that moment, Poland has achieved a lot in the field of economic convergence, mostly because of foreign direct investments, positive balance of foreign trade, access to the EU markets and structural funds, public sector investments, demographic and social changes as well as increase of Polish citizens' living standard.

Polish society and economy still have to lead the charge to adjust the difference to the top EU countries, mainly on a field of innovation. An annual report published by the European Commission, called European Innovation Scoreboard, points out that Poland has nearly the lowest in the EU innovation rate every year (European Innovation Scoreboard, 2019).

Strategy for Responsible Development by 2020 (with 2030 perspective) defines new vision and mission of Polish development, which should be based on several assumptions - stable public finances and spendings, the constant growth of citizens' living standard, protection of the natural environment, as well as, concern to raise the competitiveness of Polish enterprises. A significant part of SRD 2020/2030 was also devoted to equal redistribution of profits coming from economic growth to avoid social and territorial exclusion. Authors of the strategy point out six significant 'development challenges' which may impact and inhibit potential economic growth (Picture 2). 


\section{DEVELOPMENT CHALLENGES}

\section{OF POLISHECONOMYBY 2030}

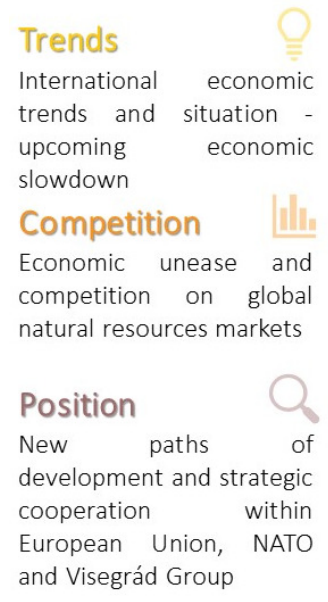

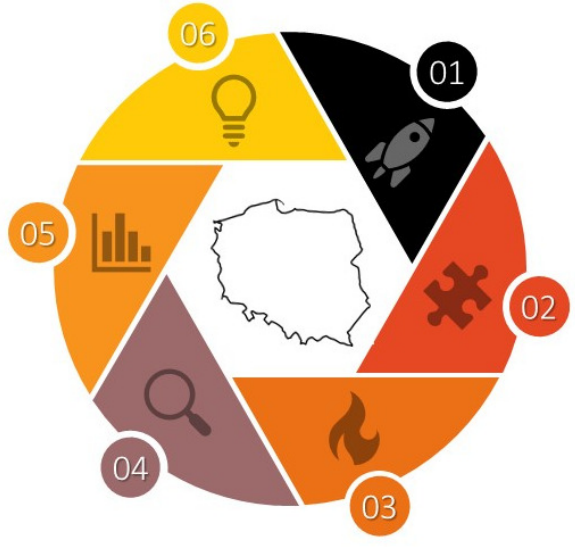

Picture 2: Development challenges of Polish economy by 2030. Source: Own elaboration based on Strategy of Responsible Development by 2020 (with 2030 perspective)

SRD 2020/2030 not only diagnoses the external threats and challenges but also aims to eradicate impediments to sustainable and responsible growth. Moreover, over the last years, Polish enterprises have been basing their competitiveness on cost factors, such as low labor costs instead of high quality of goods or innovative products and services (Zdyb, 2018). To overcome the mentioned threats and challenges, authors of the strategy established three main goals:

Permanent economic and
industrial growth based on
knowledge, data,
and organizational perfection

III. Active public institutions which serve social inclusion
Since the author of this paper is primarily focused on economic growth and development, only the first general aim was considered during the analysis because it includes specific goals titled: Reindustrialization, development of innovative enterprises, and small and medium enterprises (SRD).

Role of new structural economics in reindustrialization in Poland by 2030

New structural economics advises the authorities to discover hidden comparative advantages within national sectors and implement specific strategies to turn them into competitive advantages. Authors of the strategy made a review of the current Polish economic situation and a selection of twelve trades and industries, which may become crucial for future development or are strategically important at the moment. Those twelve areas of operation were developed into flagship programs, which are supposed to be the 'game changers' in the national economy (Table 1.) 
Table 1: Flag projects of Strategy for Responsible Development 2020 (with 2030 perspective). Source: Own elaboration based on SRD 2020/2030 and relevant publications.

FLAG PROJECTS AND EXAMPLE OF NSE IMPLEMENTATION in STRATEGY FOR RESPONSIBLE DEVELOPMENT BY 2020 (WITH 2030 PERSPECTIVE)

\begin{tabular}{|c|c|c|c|}
\hline $\begin{array}{l}\text { NAME OF } \\
\text { THE FLAG } \\
\text { PROJECT }\end{array}$ & PROJECT BRIEF SUMMARY & $\begin{array}{l}\text { TYPE OF THE INDUSTRY } \\
\text { REGARDING NSE } \\
\text { ASSUMPTIONS }\end{array}$ & $\begin{array}{c}\text { REMARKS RELATED WITH } \\
\text { CURRENT IMPLEMENTATION } \\
\text { (2019) }\end{array}$ \\
\hline 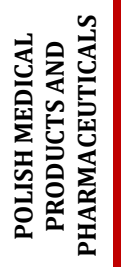 & $\begin{array}{l}\text { Development of this sector } \\
\text { combined with grants and } \\
\text { subsidies for innovative R\&D } \\
\text { projects mainly related to } 3 \mathrm{D} \\
\text { tissue printing, constructing } \\
\text { medical robots, devices } \\
\text { supporting people with } \\
\text { disabilities }\end{array}$ & $\begin{array}{l}\text { 'Catching-up industry', with } \\
\text { solid potential because of } \\
\text { leading } r \text { pharmaceutical } \\
\text { companies } r \text { such r as } \\
\text { Polpharma, TZMO, and } \\
\text { Aflofarm. }\end{array}$ & $\begin{array}{l}\text { The main activity in this field is } \\
\text { related to the Polish } \\
\text { Pharmaceutical } \\
\text { (introduced in 2018). }\end{array}$ \\
\hline 乩 & $\begin{array}{l}\text { Support for projects which } \\
\text { combine medicine and IT } \\
\text { solutions in the diagnostic } \\
\text { treatment process. }\end{array}$ & $\begin{array}{l}\text { 'Catching-up industry' } \\
\text { Currently, there is no } \\
\text { sufficient infrastructure and } \\
\text { leading firms }\end{array}$ & $\begin{array}{l}16,3 \text { million EUR - the budget for } \\
\text { the project - covers introducing } \\
\text { seven new procedures of } \\
\text { telemedicine - for example - in } \\
\text { cardiology, diabetology, palliative } \\
\text { care, geriatrics, and psychiatry. }\end{array}$ \\
\hline 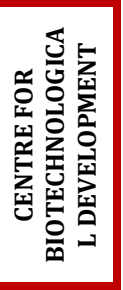 & $\begin{array}{l}\text { The project which focuses on } \\
\text { the development of new genetic } \\
\text { pharmaceuticals and process of } \\
\text { their commercialization. } \\
\text { Authorities plan to develop } \\
\text { existing research centers and } \\
\text { establish new institutions in this } \\
\text { field and also increase the value } \\
\text { of public procurements. }\end{array}$ & $\begin{array}{l}\text { 'Leading Edge Industries', } \\
\text { Polish companies may } \\
\text { become frontiers in this } \\
\text { rapidly growing field. }\end{array}$ & $\begin{array}{l}\text { Four types of support: } \\
\text { - Bio-med R\&D grant (up to } 40 \\
\text { mln EUR), } \\
\text {. INNOMED } \\
\text { (subsidies up to } 2 \text { mln EUR), } \\
\text { - } 0 \% \text { CIT within Special } \\
\text { Economic Zones, } \\
\text { - } 0 \% \text { property tax for } \\
\text { biomedical companies. }\end{array}$ \\
\hline 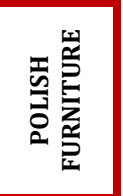 & $\begin{array}{l}\text { Support for Polish furniture } \\
\text { producers who offer modern } \\
\text { design and high-quality } \\
\text { products. }\end{array}$ & $\begin{array}{l}\text { 'Catching-up industry' in this } \\
\text { field, Poland potentially has a } \\
\text { hidden comparative } \\
\text { advantage due to low labour } \\
\text { cost and high quality of } \\
\text { exported products. }\end{array}$ & $\begin{array}{l}\text { Polish-Design Furniture Program - } \\
\text { a diverse and complex programme } \\
\text { promoting export and supporting } \\
\text { creative and innovative } \\
\text { companies. }\end{array}$ \\
\hline 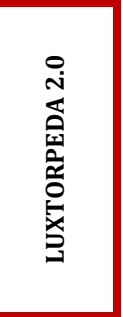 & $\begin{array}{l}\text { The project named after Polish } \\
\text { high-speed train from 1930's, } \\
\text { which is a sophisticated } \\
\text { program of railway } \\
\text { infrastructure improvement } \\
\text { and modern high-speed trains } \\
\text { production. }\end{array}$ & $\begin{array}{l}\text { 'Corner } \quad \text { overtaking' } \\
\text { industries, Polish high-speed } \\
\text { trains industry has a potential } \\
\text { but requires significant } \\
\text { governmental support }\end{array}$ & $\begin{array}{l}\text { Established in } 2017 \text { business } \\
\text { cluster "Forum for Responsible } \\
\text { Development - Luxtorpeda } 2.0 \text { '. } \\
\text { Program INNO-PKP together with } \\
\text { National Centre of Research and } \\
\text { Development (NCBiR) - public } \\
\text { procurements of } 80 \text { high-speed } \\
\text { trains, modernization of } 9000 \mathrm{~km} \\
\text { railway and } 230 \text { smaller projects } \\
\text { (by 2019) (Madrjas, 2018) }\end{array}$ \\
\hline$\stackrel{\sim}{\stackrel{m}{a}}$ & $\begin{array}{l}\text { Enhancement of the usage of } \\
\text { electric public vehicles in Polish } \\
\text { cities. }\end{array}$ & $\begin{array}{l}\text { 'Catching-up industry' with a } \\
\text { hidden comparative } \\
\text { advantage because of a very } \\
\text { high number of Li-Io batteries } \\
\text { production and influential } \\
\text { local companies like IKARIUS. }\end{array}$ & $\begin{array}{l}\text { Polish E-BUS Consortium, } \\
\text { together with NCBiR, established } \\
\text { in 2018, aims to produce } 1000 \\
\text { electric buses for public } \\
\text { transportation by } 2023 \text { for Polish } \\
\text { cities. }\end{array}$ \\
\hline
\end{tabular}

Pawel BRUSILO (2020), Journal of Eastern Europe Research in Business and Economics, DOI: $10.5171 / 2020.812353$ 


\begin{tabular}{|c|c|c|c|}
\hline 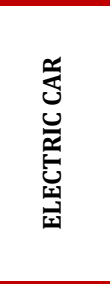 & $\begin{array}{l}\text { Similar to the previous project, } \\
\text { but in this case, the purpose is to } \\
\text { increase the number of electric } \\
\text { vehicles on Polish roads and } \\
\text { accessibility to the } \\
\text { infrastructure, such as public } \\
\text { chargers. }\end{array}$ & $\begin{array}{l}\text { 'Catching-up industry'. Very } \\
\text { challenging because there is } \\
\text { no Polish electric car } \\
\text { producer. Poland also has } \\
\text { almost the lowest number of } \\
\text { such cars 'on the roads' in the } \\
\text { EU and poor infrastructure in } \\
\text { this matter. }\end{array}$ & $\begin{array}{l}\text { Initially, one million electric cars } \\
\text { were supposed to be produced by } \\
2020 \text {, but neither new producers } \\
\text { appeared, nor the number of cars } \\
\text { significantly increased. The } \\
\text { government from } 2020 \text { only offers } \\
\text { a } 30 \% \text { public subsidy for new } \\
\text { electric cars (original retail price } \\
\text { cannot exceed } 29000 \text { EUR). }\end{array}$ \\
\hline 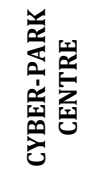 & $\begin{array}{l}\text { The project postulates opening } \\
\text { new national centers with } \\
\text { mainly IT technologies, which } \\
\text { might be developed in a field of } \\
\text { cyber-defense. }\end{array}$ & $\begin{array}{l}\text { 'Strategic' industry which is } \\
\text { marked up with high } \\
\text { importance for national } \\
\text { cyber-defense. }\end{array}$ & $\begin{array}{l}\text { Established in 2017, CYBER-PARK } \\
\text { ENIGMA - the project developing } \\
\text { solutions in fields such as the } \\
\text { Internet of Things (5G), Industry } \\
4.0 \text {, and Artificial Intelligence. }\end{array}$ \\
\hline 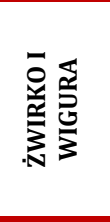 & $\begin{array}{l}\text { The project named after two } \\
\text { Polish aviation pioneers from } \\
\text { the beginning of the XX century, } \\
\text { which aims to encourage and } \\
\text { support the aeronautic industry } \\
\text { - mostly drones and uncrewed } \\
\text { planes. }\end{array}$ & $\begin{array}{l}\text { 'Catching-up industry', but the } \\
\text { project also aims to adjust the } \\
\text { law and regulations to } \\
\text { increasing usage of drones in } \\
\text { the Polish aerospace. }\end{array}$ & $\begin{array}{l}\text { In 2018, NCBiR established } \\
\text { project INNOSBZ (Innovative } \\
\text { Drones and Unmanned Planes) } \\
\text { with R\&D subsidies. National air } \\
\text { traffic control and landing system } \\
\text { for drones are in the hopper. }\end{array}$ \\
\hline 希 & $\begin{array}{l}\text { An attempt to stimulate the } \\
\text { growth of yachting and } \\
\text { innovative ferry industry } \\
\text { (Batory was first Polish } \\
\text { transatlantic liner). }\end{array}$ & $\begin{array}{l}\text { 'Comparative advantage- } \\
\text { losing industry'. This sector } \\
\text { used to be very competitive, } \\
\text { but due to structural change, } \\
\text { its importance has decreased. }\end{array}$ & $\begin{array}{l}\text { The aim fulfilled by four main } \\
\text { projects: } \\
\text { · Building proms and ferries by } \\
\text { Polish Marine Cluster, } \\
\text { - INNOship (Smart Ship } \\
\text { Technologies), } \\
\text { - I-Offshore (Innovative offshore } \\
\text { platform), } \\
\text { - Ship scrapping/Ship recycling. }\end{array}$ \\
\hline 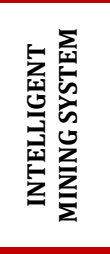 & $\begin{array}{l}\text { Supporting the development of } \\
\text { enterprises producing mining } \\
\text { machinery and modern } \\
\text { coordinating systems. }\end{array}$ & $\begin{array}{l}\text { 'Comparative advantage- } \\
\text { losing industry'. Despite the } \\
\text { international agreements and } \\
\text { EU decarbonization process, } \\
\text { the Polish government aims to } \\
\text { increase the lost } \\
\text { competitiveness of the mining } \\
\text { industry. }\end{array}$ & $\begin{array}{l}3.99 \text { billion PLN (nearly } 1 \text { billion } \\
\text { EUR) budget of the project will be } \\
\text { spent on modernization and } \\
\text { development of security and } \\
\text { coordination systems in Polish } \\
\text { mines, mostly in the Silesia region. }\end{array}$ \\
\hline 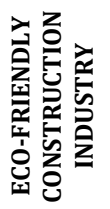 & $\begin{array}{l}\text { The project aims to put more } \\
\text { eco-friendly or energy-efficient } \\
\text { constructions on the map. }\end{array}$ & $\begin{array}{l}\text { 'Corner overtaking' industry } \\
\text { (constructing zero-emission } \\
\text { buildings and log houses) }\end{array}$ & $\begin{array}{l}\text { Ministry of Environment } \\
\text { constituted the Polish Wooden } \\
\text { Houses Co-partnership, which } \\
\text { works on the popularisation of } \\
\text { this building construction } \\
\text { technology. }\end{array}$ \\
\hline
\end{tabular}

As shown in table 1, SRD 2020/2030 projects are related to very diverse sectors of the Polish economy. Despite those twelve flag programs, there are also 173 strategic projects which fortify SRD 2020/2030 with various actions and efforts to achieve the objectives. Indubitably, a substantial amount of money and resources are required to conduct such complex operations. The government assumed that between 2016 and 2020 public sector would channel nearly 1 494,5 billion PLN
(346,8 billion EUR) to projects related to SRD 2020/2030. Regarding the tentative calculation placed in the strategy, resources are supposed to come from local and regional authorities $(33,98 \%)$, European Union funds and programs (15,81\%), national budget $(43,04 \%)$, and Polish Development Fund (7,17\%). However, authors of the SRD 2020/2030 plan to attract the attention of the private sector and convince individual entrepreneurs and institutions from the financial sector to 
spend on those projects 670 billion PLN $(155,45$ billion EUR) by 2020. Initial analysis of the projects shows that the strategy is a very complex program that aims to develop crucial sectors of the Polish economy (Ryć, 2017). Closer studies on the specific flag and strategic projects (which are supposed to lead up to a significant shift in an economic and social situation in Poland) show that each of them is modeled on new structural economics assumptions. The actions planned within the SRD $2020 / 2030$ projects correspond to postulates related to, mentioned in the introduction, six categories of catching-up sectors/industries.

The review of specific actions within each flag program shows that industrial policies were allocated correctly to each industry. Authors of the strategy emphasize the fact that the chosen sectors are not only playing a pivotal role in future Polish economic and social development but, first of all, may turn hidden comparative advantages into competitive advantages. SRD 2020/2030, matching categories and implemented industrial policy are shown in the table above.

(...) This strategy slipped past the fact that the most important development barrier is a significantly low rate of private savings (it is a very unpopular opinion in Polish society which foregrounds individual consumerist aspirations even on account). The strategy also omits another problem - how much very low tendency of Polish enterprises to internationalize and be innovative is caused by low social capital, lack of ability to cooperate and teamwork? (...)

Professor Witold Ortowski in Office of the President of the Republic of Poland

Since the first presentation of SRD 2020/2030 initial conception in 2016, Deputy Prime Minister Mateusz Morawiecki (current Prime Minister) in Ministry of Development has been facing dissenting voices and criticism from entrepreneurs, representants of local governments, academic society and even National Development Council in Office of the President of the Republic of Poland. This council was raising the voice against the strategy mostly in the field of shortcomings in the legislative standards and missing essential required elements such as lack of so-called roadmap with described milestones (referencing to the Parliament regulation from 2006 - About a development strategy conduction). Regarding the legitimatized criticism related to a form of the strategy, experts raise the fact that statutory law from 2006 established legal requirements for strategies on the national, sectoral, and regional level, so those missing sections undermine SRD 2020/2030 credibility.

Council emphasizes that the goals and strategic catching-up sectors are undoubtedly appropriately defined, but the description of the individual projects (including flag projects) is not sufficiently elaborated, which may cause problems with implementation. Last but not least, arguments raised by the National Development Council state that such tremendous planned resources require much more comprehensive arrangements and descriptions (i.e., with an explanation of how local authorities will be able to cover one-third of public spendings on SRD 2020/2030). Experts from Polish Economic Association also criticized the 
lack of adjustment to European Union directives related to the decarbonization of the economy, a decrease of greenhouse gas emission, and protection of the natural environment (Bukowski, Olko, Stefanowicz, 2016). The next argument of PEA against the strategy is considerably fundamental there is no cost-benefit analysis in SRD $2020 / 2030$, which is a substantial element of every strategy. Such studies might present what the project's future cash flows or net benefits are. Despite these concerns, some economics tried to show potential befits of SRD 2020/2030 implementation. All those arguments mentioned above make the evaluation of SRD 2020/2030 a complex challenge. However, some of the statistical data show that possibly the strategy has a positive impact already - between 2015 and 2018, the adjusted gross disposable income of households per capita in PPS in Poland increased from 15,135 up to 16,251 (Eurostat). On the one hand, this document does not face critical requirements of a legal definition of 'strategy' due to missing parts, but despite this - thesis and goals are correctly formulated, and their implementation may accelerate Polish economic development. The following results of the research show that the implementation of the strategy after nearly four years is neither effective nor successful.

\author{
(...) The objectives of the Strategy for Responsible \\ Development largely respond to the needs existing at \\ the current stage of Poland's development. Its main \\ goal is to create conditions for increasing Poles, \\ incomes while improving social, economic and \\ territorial cohesion. The effects of the implementation \\ of the new idea of Poland's socio-economic \\ development will be possible to asses after several \\ years of implementation (...) \\ $\sim$ Professor Alojzy Z. Nowak \\ 'New structural economics and dilemmas of the \\ economic development', University of Warsaw, 2017
}

\section{Conclusions}

Conducted research and analysis proved that new structural economics was instrumental in the process of shaping postulates of Polish Strategy for Responsible Development by 2020 (with 2030 perspective). Authors of SRD $2020 / 2030$ had not only accurately chosen significant industries, but also allocated suitable policies and actions relevant to NSE assumptions. Evaluation of 'flag projects' and the strategy itself was critical because this document and current central authorities shape future conditions in Poland - but is it the best path or go-to option? Changes in economic and social structure are incredibly important, but to implement any distinct improvements, the Polish situation requires active, authentic leaders and a complex, refined strategy.
The assumptions of new structural economics are undoubtedly an interesting way of thinking about the development of less advanced countries and catching-up economies. An example of SRD 2020/2030 shows that the implementation of them is possible in countries like Poland. What brings out from the study is the fact that the theoretical background of the strategy is correct, while the problem lies with thesis deployment and implementation of investments. I hope that the results of the research may shed some light on the matter of SRD 2020/2030 and the role of new structural economics in shaping middleincome countries, such as Poland.

\section{Acknowledgments}

The publication of the research presented above was financially supported by the Ministry of Science and Higher Education in Poland under the program "Regional 
Initiative of Excellence" INTEREKON 2019 2022, project number 015/RID/2018/19 (total program funding amount: 10721 040,00 PLN) and thanks to Wroclaw University of Economics and Business.

\section{References}

1. Bruno, R.L., Douarin, E., Korosteleva, J. and Radosevic, S. (2015) 'Technology choices and growth: testing new structural economics in Transition Economies'. Journal of Economic Policy Reform 18 (2), 131-152.

2. Bukowski, M., Olko, D. and Stefanowicz, J. (2016) 'Strategia na rzecz Odpowiedzialnego Rozwoju' w ocenie ekspertów z TEP [Online] Polish Economic Association [Retrieved: February 25, 2020], www.tep.org.pl.

3. European Commission (2019) European Innovation Scoreboard 2019 [Online], EC [Retrieved: February 25, 2020] www.ec.europa.eu.

4. Eurostat's Open Data (2019) Adjusted gross disposable income of households per capita in PPS [Online] Eurostat Data [Retrieved: February 25, 2020] www.ec.europa.eu

5. Government of Republic of Poland (15.03.2017). W sprawie przyjęcia Strategii na rzecz Odpowiedzialnego Rozwoju do roku 2020 (z perspektywa do 2030 r.) (Resolution in the adoption of Strategy for Responsible Development by 2020 (with 2030 perspective)), Government resolution (RP) no. 260.

6. Krugman, P. R. and Obstfeld, M., (2018) International Economics. Theory and Politics., PWN SA., Warsaw.

7. Lin, J. Y. (2011) 'Six steps for strategic government intervention', Global Policy, 1 (2), 150-161.

8. Lin, J. Y. and Nowak, A.Z. (2017) New structural economics for less advanced countries, University of Warsaw: Faculty of Management Press, Warsaw.
9. Lin, J. Y. (2010) 'New structural economics: A Framework for Rethinking Development', Policy Research Working Paper no. 5197.

10. Madrjas, J. (2019) 'Dziewięć firm chce zaprojektować z PKP Intercity pociągi do obsługi CPK' [Online]. Rynek Lotniczy [Retrieved: February 25, 2020] www.rynek-lotniczy.pl.

11. National Development Council (2016) 'Opinia o projekcie Strategii na rzecz Odpowiedzialnego Rozwoju, materiał Zespołu Zadaniowego do spraw oceny projektu SOR' (Opinion about Strategy for Responsible Development) [Online]. NDC [Retrieved: February 25, 2020] www.prezydent.pl

12. Parliament of Republic of Poland (06.12.2006). 'O zasadach prowadzenia polityki rozwoju' (About a development strategy conduction) Parliament regulation (RP) no. 227, position 1658.

13. Poskrobko, T. (2012) 'Nowe koncepcje i teorie rozwoju w ekonomii, Wyzwania współczesnej ekonomii'. Difin, Warsaw.

14. Ryć, K. (2017). 'The expiring real convergence process under conditions of the common market - how to counteract' in Lin J. Y., Nowak A.Z. (2017) 'New structural economics for less advanced countries'. University of Warsaw: Faculty of Management Press, Warsaw, p. 69 - 79.

15. Woźniak, M. G. (2018) 'Nowa ekonomia w kontekście rozwoju zintegrowanego' Nierówności Społeczne, a Wzrost Gospodarczy, no. 54 (2/2018). Crocow University of Economics, p. $34-53$

16. Zdyb, M. (2018) 'Podstawowe zasady (standardy) ładu gospodarczego w świetle ustawy z 6.3.2018 r., Prawo przedsiębiorców', Monitor Prawniczy 13/2018, C. H. Beck. 